\title{
KEUNGGULANLEARNING MANAGEMENT SYSTEM EDMODO BERBASIS SMARTPHONETERHADAP KOMPUTER PADA HASIL BELAJAR SISWA
}

\author{
Sonalita Wiguna ${ }^{1}$, Subiyanto ${ }^{2}$ \\ ${ }^{1,2}$ Program Studi Pendidikan Teknik Informatika dan Komputer, Fakultas Teknik, Universitas \\ Negeri Semarang, \\ Gedung H Kampus Sekaran Gunungpati Semarang \\ ${ }^{1}$ wigunasonalita@gmail.com
}

\begin{abstract}
Abstrak
Artikel ini bertujuan mengetahui kefektivan edmodo bagi siswa yang menggunakan komputer, dan smartphone terhadap hasil belajar siswa pada mata pelajaran Bahasa Inggris di Sekolah Menengah Kejuruan. Penelitian ini membandingkan dua kelompok: (a) komputer, diajarkan menggunakan Edmodo diakses oleh komputer, dan (b) smartphone, diajarkan menggunakan aplikasi Edmodo di smartphone. Penelitian ini merupakan penelitian kuasi eksperimen dengan populasi siswa kelas X, XI, XII SMK di Kota Semarang yang menerapkan Kurikulum 2013. Sampel sebanyak tiga sekolah yang ditentukan menggunakan teknik Nonprobability Sampling dengan memilih teknik sampling purposive. Sekolah yang dijadikan sampel yakni SMK Negeri 2 Semarang, SMK Negeri 10 Semarang, dan SMK Negeri 5 Semarang. Data dianalisis menggunakan statistic deskriptif untuk menghitung nilai tertinggi, nilai terendah, standar deviasi, dan rerata n-gain, serta uji-t sample independent untuk menguji hipotesis terhadap hipotesisnol (Ho). Hasil penelitian menunjukkan kelompok smartphone memiliki perolehan skor lebih tinggi daripadakelompok komputer.
\end{abstract}

Kata Kunci: e-learnig, edmodo, mobile learning, computer learning.

\begin{abstract}
This article was to determine the effectiveness of Edmodo for students using Computer-based, and smartphone towards students' achievement in English subject. The study compared two groups: (a) computer, taught using Edmodo accessed by computer, and (b) smartphone, taught using Edmodo accessed by smartphone application. This research was quasi experimental design with all the students' population grade X, XI, XII of Semarang applied curiculum 2013. The Sample of this research were selecting by using purposive sampling technique, the sample of this research were SMK Negeri 2 Semarang, SMK Negeri 10 Semarang, and SMK Negeri 5 Seamrang. Data were analyzed using descriptive statistics to calculate the highest score, lowest score, standard deviation, and n-gain average, and t-sample independent test to test hypothesis towards null hypothesis (Ho). Research has shown that showed that the smartphone group has a higher score than the computer group.
\end{abstract}

Keywords: edmodo, smartphone, computer learning. 


\section{PENDAHULUAN}

Pendidikan adalah suatu sistem yang di dalamnya terdapat proses pembelajaran dimana siswa mampu mengembangkan potensi yang dimilikinya. Sejalan dengan adanya hal itu menurut Undang - Undang No. 20 Tahun 2015 tentang Sistem Pendidikan Nasional yang dimaksud dengan pendidikan adalah usaha sadar dan terencana untuk mewujudkan suasana belajar dan proses pembelajaran agar peserta didik secara aktif mengembangkan potensi dimana untuk memiliki kekuatan spiritual keagamaan, pengendalian diri, kepribadian, kecerdikan, akhlak mulia, serta keterampilan yang diperlukan dirinya, masyarakat, bangsa, dan negara. Visi pendidikan nasional adalah terwujudnya sistem pendidikan sebagai perantara sosial yang kuat dan berwibawa untuk memberdayakan semua warga negara Indonesia berkembang menjadi manusia yang berkualitas, sehingga mampu dan proaktif menjawab tantangan zaman yang selalu berubah.

Kegiatan pembelajaran merupakan suatu proses komunikasi dan informasi dari pendidik ke peserta didik yang berisi informasi-informasi pengetahuan. Pendidik sebagai sumber informasi; media sebagai sarana penyajian ide, gagasan, dan materi pendidikan; serta peserta didik sebagai penerima informasi. Salah satu produk TIK yang dapat dimanfaatkan untuk menunjang pembelajaran adalah internet. Pemanfaatan media internet telah melahirkan konsep pembelajaran jarak jauh berbasis elektronik yang disebut dengan e-learning. E-learning merupakan proses pembelajaran yang memanfaatkan fasilitas internet sebagai salah satu sarana dan media dalam pembelajaran.

Menurut Patmanthara (2014) e-learning adalah pembelajaran berbantuan TIK dengan menggunakan piranti elektronik, jaringan, dan perangkat lunak pengajaran yang dilengkapi dengan fasilitas komunikasi, pemantauan, dan evaluasi. E-learning dapat didefinisikan sebagai sebuah bentuk dunia maya untuk membuat sebuah transformasi proses pembelajaran di sekolah atau perguruan tinggi ke dalam bentuk digital yang dijembatani teknologi internet (Clark \& Mayer, 2008; Munir, 2009; dan Rusman dkk, 2011). Hasil riset Said, dkk (2015) membuktikan bahwa $e$-learning mampu memberikan hasil yang lebih baik dari sisi 
hasil pembelajaran mahasiswa di perguruan tinggi daripada model pembelajaran tatap muka.

Pemanfaatan teknologi informasi seperti e-learning salah satunya Edmodo akan membawa perubahan yang berarti, materi yang akan disampaikan, serta pelaksanaan proses instruksional dan pembelajaran. Penggunaan edmodo pada pembelajaran e-learning diharapkan menjadi alternatif untuk mengatasi masalah kemandirian belajar yang sering dijumpai, karena penggunaan media ini memungkinkan untuk mengajarkan siswa mencari dan mempelajari ilmu pengetahuan yang lebih luas di dunia internet agar mampu memunculkan kreativitas siswa dalam mempelajari ilmu pengetahuan, dan juga melatih peserta didik dalam mengoperasikan perangkat teknologi informasi, karena masih banyak ditemukan dilapangan yang masih gagap terhadap pemakaian teknologi (Wijaya \& Arsyah, 2015).

Keputusan untuk memilih Edmodo sebagai alternatif media pembelajaran e-learning adalah karena Edmodo mampu memberikan tata kelola pembelajaran yang lebih baik dan mudah. Edmodo mempunyai kemampuan untuk memfasilitasi kelas digital dan komunitas pembelajaran yang besar dan efektif (Cherner dkk, 2016).

Bahasa Inggris sebagai bahasa internasional sangat berguna, terutama dalam hubungan internasional. Namun, di negara-negara yang menggunakan bahasa sebagai bahasa nasional seperti Indonesia, penggunaan bahasa asing seperti bahasa Inggris sangat jarang, sehingga muncul anggapan bahwa bahasa asing sulit dipelajari di lingkungan sekolah. Selain itu, motivasi siswa, paparan yang tidak memadai, kecakapan dalam bahasa Inggris tidak sebaik yang seharusnya juga mempengaruhi kemampuan berbahasa Inggris (Normazidah dkk., 2012; Wong dkk, 2015). Pada artikel lain Adriana, 2014 menyatakan bahwa:

The international business environment is presently governed by the use of business English, which consequently led to an increasing concern about how we teach and learn business English. The current technological development has driven radical changes in our society, with the ongoing creation of new products and services, new means of managing business, new markets and investment opportunities, new social and cultural expressions, and new channels for people to communicate at global level. 
Lingkungan bisnis internasional saat ini diatur oleh penggunaan bahasa Inggris, yang akibatnya menyebabkan meningkatnya kekhawatiran tentang bagaimana kita mengajar dan belajar bahasa Inggris. Perkembangan teknologi saat ini telah mendorong perubahan radikal dalam masyarakat kita, dengan penciptaan produk dan layanan baru, cara baru mengelola bisnis, pasar baru dan peluang investasi, ekspresi sosial dan budaya baru, dan saluran baru bagi orang untuk berkomunikasi di tingkat global. Tujuan penelitian ini adalah untuk menguji kefektivan edmodo dengan komputer dan edmodo dengan smartphone terhadap hasil belajar siswa SMK Negeri di Kota Semarang pada mata pelajaran Bahasa Inggris.

\section{METODE}

Penelitian ini didesain sebagai penelitian kuasi eksperimen (eksperimen semu). Desain yang digunakan dalam penelitian quasi eksperimen ini adalah pretest-posttest control groups design. Pada penelitian ini melibatkan dua variabel, yaitu variabel bebas dan variabel terikat. Variabel bebas penelitian ini adalah jenis edmodo, sedangkan variabel terikat dalam penelitian ini adalah hasil belajar siswa. Tahapan penelitian disajikan pada Gambar 1.

Populasi dalam penelitian ini adalah seluruh siswa kelas X, XI, XII SMK Negeri 2 Semarang, SMK Negeri 5 Semarang, SMK Negeri 10 Semarang. Sampel sekolah ditentukan dengan menggunakan teknik Nonprobability Sampling dengan memilih teknik sampling purposive. Pertimbangan penentuan sampel dalam penelitian ini adalah sampel memiliki kemampuan dan karakteristik yang sama. Dalam hal ini jumlah seluruh sampel ada 211 siswa dari tiga SMK Negeri di Kota Semarang. Pada Sekolah 1 terdiri dari 36 siswa kelas kontrol, 35 siswa kelas eksperimen; Sekolah 2 terdiri dari 33 siswa kelas kontrol, 36 siswa kelas eksperimen; Sekolah 3 terdiri dari 36 siswa kelas kontrol, 35 siswa kelas eksperimen. Kelas kontrol mengerjakan tugas melalui edmodo yang diakses melalui komputer, sedangkan kelas eksperimen mengerjakan tugas menggunakan aplikasi edmodo di smartphone. 


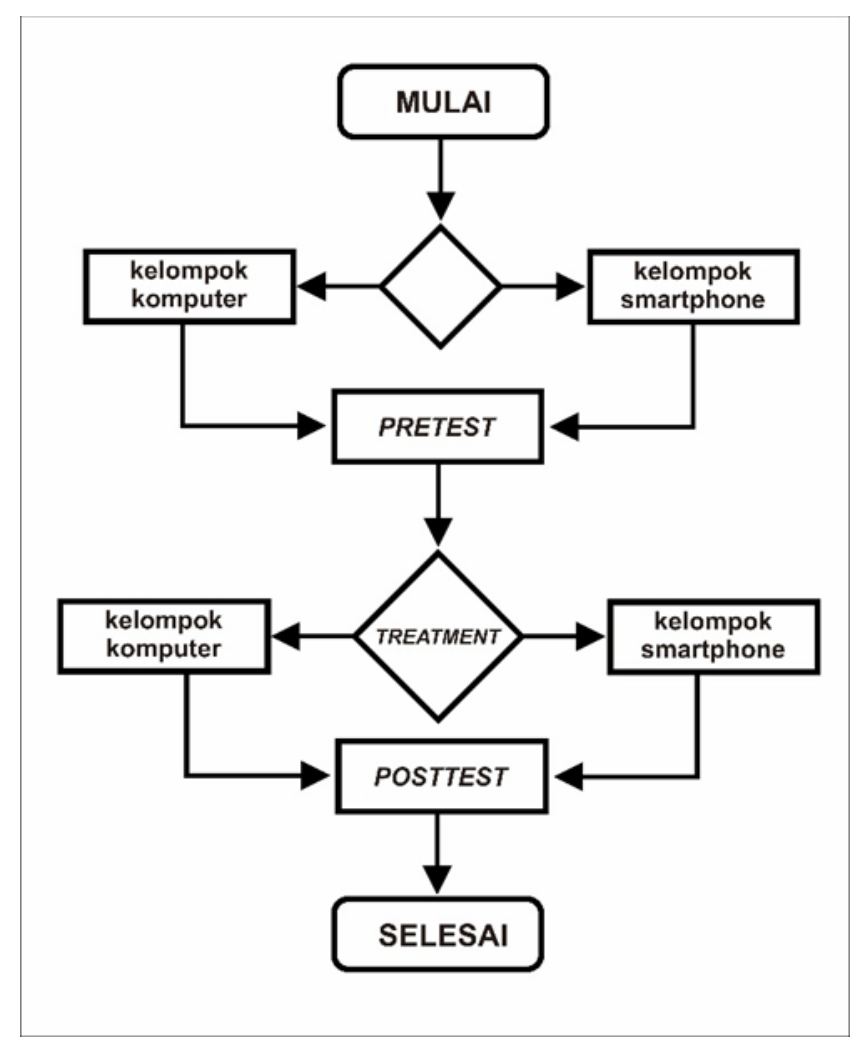

Gambar 1. Tahapan Penelitian

Instrumen yang digunakan terdiri dari soal pretest-posttest dan soal tugas mandiri yang diberikan pada tahap perlakuan. Soal pretest-posttest terdiri dari 20 soal pilihan ganda. Soal tugas mandiri terdiri dari 10 soal pilihan ganda pada masing-masing kelasnya.

Data hasil belajar siswa diperoleh melalui nilai hasil mengerjakan soal pretest-posttest sebelum dan sesudah perlakuan. Nilai tersebut dianalisis peningkatannya dengan rumus normalized-gain (N-gain). Rumus untuk menghitung n-gain diadopsi dari Hake (1998) pada persamaan 1.

$$
N-\text { gain }=\frac{\text { skor posttes }- \text { skor pretest }}{\text { skor maksimal }- \text { skor pretest }}
$$

Klasifikasi hasil belajar siswa diinterpretasikan dari hasil n-gain yang diperoleh dengan kategori yang disajikan pada Tabel 1. 
Tabel 1 Kategori $N$-Gain

\begin{tabular}{cc}
\hline Nilai $\boldsymbol{N}$-Gain & Kategori \\
\hline$N$-Gain $\geq 0,7$ & Tinggi \\
$0,3<N$-Gain $<0,7$ & Sedang \\
$N$-Gain $\leq 0,3$ & Rendah \\
\hline
\end{tabular}

Analisis data yang digunakan dalam penelitian ini yaitu statistik deskriptif dan statistitk inferensial. Statistik deskriptif dilakukan dengan menghitung nilai tertinggi, nilai terendah, standar deviasi, dan rerata n-gain. Statistik inferensial dilakukan untuk menguji hipotesis. Sebelum melakukan pengujian hipotesis, dilakukan uji prasyarat analisis data yaitu uji normalitas dan uji homogenitas. Pengujian hipotesis terhadap hipotesis nol (Ho) dilakukan dengan menggunakan uji paired sample t-test dengan Tabel kriteria Uji t-test menurut Sugiyono (2010) disajikan pada Tabel 2.

Tabel 2 Kriteria Hipotesis

\begin{tabular}{cc}
\hline Batasan & Kategori \\
\hline$t_{\text {hitung }}>t_{\text {tabel }}$ & Diterima \\
$t_{\text {hitung }}<t_{\text {tabel }}$ & Ditolak \\
\hline
\end{tabular}

\section{HASIL DAN PEMBAHASAN}

Data awal adalah data sebelum dilakukan treatment. Data awal didapat dari pretest semua kelompok untuk mengetahui kemampuan awal siswa sebelum dilakukan perlakuan. Data akhir adalah data sesudah dilakukan treatment, data akhir didapat dari posttest untuk mengetahui keefektivan jenis edmodo. Data pretest mengenai keefektivan jenis edmodo disajikan pada Tabel 3, sedangkan data posttest mengenai keefektivan jenis Edmodo disajikan pada Tabel 4.

Tabel 3. Data Pretest

\begin{tabular}{ccccccc}
\hline Sekolah & Kelompok & Peserta & $\begin{array}{c}\text { Skor } \\
\text { Tertinggi }\end{array}$ & $\begin{array}{c}\text { Skor } \\
\text { Terendah }\end{array}$ & $\begin{array}{c}\text { Rata- } \\
\text { rata }\end{array}$ & $\begin{array}{c}\text { Standar } \\
\text { Deviasi }\end{array}$ \\
\hline Sekolah 1 & Kontrol & 36 & 92 & 36 & 69,5 & 10,97 \\
& Eksperimen & 35 & 80 & 40 & 62,91 & 10,55 \\
Sekolah 2 & Kontrol & 33 & 80 & 40 & 62,79 & 10,79 \\
& Eksperimen & 36 & 84 & 60 & 69,33 & 6,38 \\
Sekolah 3 & Kontrol & 36 & 86 & 44 & 64,22 & 10,91 \\
& Eksperimen & 35 & 92 & 50 & 69,6 & 10,79 \\
\hline
\end{tabular}


Tabel 4. Data Posttest

\begin{tabular}{ccccccc}
\hline Sekolah & Kelompok & Peserta & $\begin{array}{c}\text { Skor } \\
\text { Tertinggi }\end{array}$ & $\begin{array}{c}\text { Skor } \\
\text { Terendah }\end{array}$ & $\begin{array}{c}\text { Rata- } \\
\text { rata }\end{array}$ & $\begin{array}{c}\text { Standar } \\
\text { Deviasi }\end{array}$ \\
\hline Sekolah 1 & Kontrol & 36 & 90 & 60 & 78,14 & 7,35 \\
& Eksperimen & 35 & 96 & 76 & 87,89 & 4,44 \\
Sekolah 2 & Kontrol & 33 & 84 & 56 & 74,55 & 9,3 \\
& Eksperimen & 36 & 90 & 78 & 84 & 3,31 \\
Sekolah 3 & Kontrol & 36 & 96 & 56 & 79,22 & 9,05 \\
& Eksperimen & 35 & 94 & 78 & 86,69 & 4,23 \\
\hline
\end{tabular}

Uji prasyarat analisis dilakukan terhadap nilai n-gain untuk mengetahui normalitas dan homogenitas data yang digunakan sebelum dilakukan uji hipotesis. Uji normalitas menggunakan uji Saphiro-Wilk, sedangkan uji homogenitas menggunakan uji Levene test dengan bantuan program SPSS 22. Ringkasan hasil uji normalitas disajikan pada Tabel 5.

Tabel 5. Uji Normalitas

\begin{tabular}{|c|c|c|c|c|c|}
\hline \multirow{2}{*}{ Sekolah } & \multirow{2}{*}{ Kelompok } & \multirow{2}{*}{ Data } & \multicolumn{2}{|c|}{ Uii T-test } & \multirow{2}{*}{ Kriteria } \\
\hline & & & Sig & $\alpha$ & \\
\hline \multirow[t]{4}{*}{ Sekolah 1} & Kontrol & Pretest & 0,06 & 0,05 & Berdistribusi Normal \\
\hline & & Posttest & 0,22 & 0,05 & Berdistribusi Normal \\
\hline & Eksperimen & Pretest & 0,23 & 0,05 & Berdistribusi Normal \\
\hline & & Posttest & 0,60 & 0,05 & Berdistribusi Normal \\
\hline \multirow[t]{4}{*}{ Sekolah 2} & Kontrol & Pretest & 0,34 & 0,05 & Berdistribusi Normal \\
\hline & & Posttest & 0,07 & 0,05 & Berdistribusi Normal \\
\hline & Eksperimen & Pretest & 0,81 & 0,05 & Berdistribusi Normal \\
\hline & & Posttest & 0,75 & 0,05 & Berdistribusi Normal \\
\hline \multirow[t]{4}{*}{ Sekolah 3} & Kontrol & Pretest & 0,08 & 0,05 & Berdistribusi Normal \\
\hline & & Posttest & 0,56 & 0,05 & Berdistribusi Normal \\
\hline & Eksperimen & Pretest & 0,08 & 0,05 & Berdistribusi Normal \\
\hline & & Posttest & 0,70 & 0,05 & Berdistribusi Normal \\
\hline
\end{tabular}

Berdasarkan hasil uji normalitas, data $N$-gain dari ketiga sekolah masingmasing memenuhi kriteria berdistribusi normal sehingga dilanjutkan uji asumsi homogenitas. Ringkasan hasil uji homogenitas disajikan pada Tabel 6. 
Tabel 6. Uji Homogenitas

\begin{tabular}{clccl}
\hline \multirow{2}{*}{ Sekolah } & \multirow{2}{*}{ Data } & \multicolumn{2}{c}{ Uji Homogen } & \multirow{2}{*}{ Kriteria } \\
\cline { 3 - 4 } & & Sig & A & \\
\hline \multirow{2}{*}{ Sekolah 1 } & Pretest & 0,975 & 0,05 & Homogen \\
& Posttest & 0,159 & 0,05 & Homogen \\
Sekolah 2 & Pretest & 0,401 & 0,05 & Homogen \\
& Posttest & 0,090 & 0,05 & Homogen \\
Sekolah 3 & Pretest & 0,784 & 0,05 & Homogen \\
& Posttest & 0,860 & 0,05 & Homogen \\
\hline
\end{tabular}

Berdasarkan Tabel 6, data dari ketiga sekolah masing-masing memenuhi uji homogenitas Kondisi tersebut berarti bahwa data semua kelompok untuk masingmasing sekolah memiliki varian yang sama, sehingga uji hipotesis dengan uji-t sample independent dapat dilanjutkan. Ringkasan hasil uji hipotesis untuk masingmasing sekolah disajikan pada Tabel 7.

Tabel 7. Uji T-test

\begin{tabular}{llccccc}
\hline \multirow{2}{*}{ Sekolah } & \multirow{2}{*}{ Kelompok } & \multirow{2}{*}{ Peserta } & \multirow{2}{*}{ df } & \multicolumn{2}{c}{ Uji T-test } & \multirow{2}{*}{ t } \\
\cline { 5 - 6 } Sekolah 1 & Kontrol & 36 & 35 & 0,001 & 0,05 & $-3,713$ \\
& Eksperimen & 35 & 34 & 0,000 & 0,05 & $-12,556$ \\
\multirow{2}{*}{ Sekolah 2 } & Kontrol & 33 & 32 & 0,000 & 0,05 & $-4,953$ \\
& Eksperimen & 36 & 35 & 0,000 & 0,05 & $-11,712$ \\
\multirow{2}{*}{ Sekolah 3 } & Kontrol & 36 & 35 & 0,000 & 0,05 & $-5,732$ \\
& Eksperimen & 35 & 34 & 0,000 & 0,05 & $-9,109$ \\
\hline
\end{tabular}

Setelah dilakukan uji t-test kemudian dilakukan uji peningkatan rata-rata $(N$-gain) dilakukan untuk mengetahui besar rata-rata peningkatan rata-rata hasil belajar siswa sebelum dan setelah perlakuan. Hasil uji $N$-gain ditampilkan dalam Tabel 8.

Tabel 8. Uji N-gain

\begin{tabular}{|c|c|c|c|c|c|}
\hline \multirow{2}{*}{ Sekolah } & \multirow{2}{*}{ Kelompok } & \multicolumn{2}{|c|}{ Rata-rata } & \multirow{2}{*}{$N$-gain } & \multirow{2}{*}{ Kriteria } \\
\hline & & Pretest & Posttest & & \\
\hline \multirow[t]{2}{*}{ Sekolah 1} & Kontrol & 69,5 & 78,14 & 0,3 & Rendah \\
\hline & Eksperimen & 62,91 & 87,89 & 0,7 & Tinggi \\
\hline \multirow[t]{2}{*}{ Sekolah 2} & Kontrol & 62,79 & 74,55 & 0,3 & Rendah \\
\hline & Eksperimen & 69,33 & 84 & 0,5 & Sedang \\
\hline \multirow[t]{2}{*}{ Sekolah 3} & Kontrol & 64,22 & 79,22 & 0,4 & Sedang \\
\hline & Eksperimen & 69,6 & 86,69 & 0,6 & Sedang \\
\hline
\end{tabular}


Berdasarkan Tabel 7, dapat dilihat dari Sig (2-tailed) yang sebesar 0,000. Nilai Sig (2-tailed) sebesar 0,000<0,05 maka Ho ditolak dan Ha diterima yang artinya terdapat perbedaan secara signifikan antara kelas eksperimen dengan kelas kontrol. Dapat disimpulkan pada seluruh sekolah bahwa kelas eksperimen secara signifikan lebih tinggi dibandingkan kelas kontrol.

Berdasarkan Tabel 8, dapat dilihat bahwa peningkatan rata-rata kelompok MBA memiliki nilai yang lebih tinggi dibanding kelompok lainnya. Dengan demikian keloimpok MBA memiliki tingkat kefektivan lebih tinggi dibanding kelompok lainnya. Temuan ini sejalan dengan penelitian terdahulu yang dilakukan (Stavros \& Anastasios, 2015) menyatakan bahwa kelompok yang menggunakan smartphone memiliki nilai belajar dan motivasi yang lebih baik dibanding kelompok yang menggunakan kertas dan komputer.

Penggunaan aplikasi edmodo dalam mobile learning dapat meningkatkan efektivitas dalam pembelajaran karena fasilitas dalam edmodo mampu meningkatkan efektivitas komunikasi dalam pembelajaran dan siswa dapat diakses dimanapun dan kapanpun (Khaleel, 2015). Selain itu, riset Kosasi (2015) menunjukkan bahwa e-learning sendiri juga mampu meningkatkan motivasi karena keinteraktifannya. Artinya, e-learning mampu menambah kualitas interaksi guru dan murid apabila memanfaatkan fitur komunikasi yang ada di dalamnya, seperti group chat, comment, quiz, dan lain sebagainya.

\section{SIMPULAN}

Berdasarkan hasil penelitian dan pembahasan disimpulkan bahwa edmodo berbasis smartphone lebih efektiv untuk meningkatkan hasil belajar siswa. Edmodo memberi fasilitas bagi guru dan murid, tempat yang aman untuk berkomunikasi, berkolaborasi, berbagi konten dan aplikasi pembelajaran, tugas bagi mahasiswa, diskusi dalam kelas virtual, ulangan secara online, nilai dan diskusi. Pada intinya edmodo menyediakan semua yang bisa dilakukan di kelas dalam kegiatan pembelajaran. 


\section{UCAPAN TERIMA KASIH}

Penelitian ini didukung oleh UNNES Electrical Engineering Students Research Groups (UEESRG). Jurusan Teknik elektro Universitas Negeri Semarang. Ucapan Terima Kasih untuk SMK Negeri 2 Semarang, SMK Negeri 5 Semarang, SMK Negeri 10 Semarang.

\section{DAFTAR PUSTAKA}

Adriana Teodorescu. (2014). Mobile learning and its impact on business English learning. The 6th International Conference Edu World 2014 Education Facing Contemporary World Issues. Procedia Social and Behavioral Sciences. 1535-1540.

Cherner, T., Lee, C-Y., Fegely, A., \& Santaniello, L. (2016). A Detailed Rubric for Assessing the Quality of Teacher Resource Apps. Journal of Information Technology Education: Innovations in Practice. Vol. 15, Hal. 117-143.

Clark, R.C. \& Mayer, R.E. (2008). E-Learning and The Science of Instruction: Proven Guidelines for Consumers and Designers of Multimedia Learning, Second Edition. San Francisco: John Wiley \& Sons, Inc.

Hake, Richard R., "Analyzing Change/Gain Scores" dalam www.physycs.indiana.edu/ sdi/AnalysingChange-Gain.pdf.

Khaleel M. Al-Said. (2015). Students' Perceptions of Edmodo and Mobile Learning and their Real Barriers towards them. TOJET: The Turkish Online Journal of Educational Technology, Vol. 14, No. 2, Hlm. 167-180.

Kosasi, S. (2015). Perancangan E-learning Untuk Meningkatkan Motivasi Belajar Guru dan Siswa. Prosiding Seminar Nasional Pendidikan Teknik Informatika (Senapati), Singaraja, Bali, 12 September 2015. Hal. 82-88.

Munir. (2009). Pembelajaran Jarak Jauh Berbasis Teknologi Informasi dan Komunikasi. Bandung: Alfabeta.

Normazidah Che Musa, Koo Yew Lie, Hazita Azman. (2012). Exploring English languange learning and teaching in Malaysia. UKM Journal. Vol. 12, No. 1, Hal. 35-51. 
Parmanthara, S. (2014). Komputer Dalam Pembelajaran $\left(1^{s t} E d\right)$. Jember: Cerdas Ulet Kreatif.

Rusman, dkk. (2011). Pembelajaran Berbasis Teknologi Informasi dan Komunikasi : Mengembangkan Profesionalisme Guru. Jakarta:Rajawali Pers. PT. Raja Grafindo Persada

Said, H., Kirgis, L., Verkamp, B., \& Johnson, L. (2015). Online vs. Face-to-Face Delivery of Information Technology Courses: Students' Assessment. Journal of Information Technology Education: Research. Vol. 14, No. 1, Hal. 297-312.

Sugiyono. (2010). Metode Penelitian Pendidikan Pendekatan Kuantitatif, Kualitatif dan $R \& D$. Bandung: Alfabeta.

Stavros A. Nikou \& Anastasios A. Economides. (2015). The impact of paperbased, computer-based and mobile-based selfassessment on students' science motivation and achievement. Computers in Human Behavior. Hal. $1-8$.

Wijaya, Indra \& Arsyah, Rahmatul Husna. (2015). Pengaruh Pembelajaran ELearning Berbasis Edmodo Terhadap Hasil Belajar Simulasi Digital Kelas X SMK Negeri 9 Padang. Majalah Ilmiah UPI YPTK, Vol. 22, No. 1, Hal. 21-33.

Wong Seng Yue, Wee Jing Tee, Mohamad Al-Azhar Bin Jasman. (2015). 2D Side-Scrolling Game: Applying Motivation and Digital Game-Based Learning (DGBL) in English Learning. Taylor's 7th Teaching and Learning Conference 2014 Proceedings: 349-358. 